\title{
A határhatás irodalom áttekintése - Torzítják-e az országhatárok a kereskedelmi kapcsolatokat?
}

\author{
MÁRKUS ÁDÁM \\ ügyvivö-szakértö, Debreceni Egyetem, Gazdaságtudományi kar \\ E-mail:markus.adam@econ.unideb.hu
}

\begin{abstract}
A cikk egy Magyarországon eddig kevésbé elemzett problémáról, a határhatásról (border effect) és annak empirikus kutatásáról kíván átfogó képet adni. A témában született tanulmányok - szinte kivétel nélkül - rávilágítanak arra a tényre, hogy az országhatárok jelentősen korlátozzák a nemzetközi árukapcsolatok kibontakozását, ceteris paribus. Az országok kereskedelme torzulást mutat a belföldi piacok felé, amit egyfelől logikusan meg lehet magyarázni olyan tényezőkkel, mint az országok közötti jövedelemkülönbségek, távolságok, vámok és egyéb korlátozások, kulturális eltérések vagy eltérő valuták, másfelöl viszont még ezeket a tényezőket kontrollálva is jellemző lehet a belföldi partnerek favorizálása, ami egyfajta indokolatlan vagy túlzott preferálás irányába mutat. Az irodalom-áttekintő cikk a különböző gravitációs modellspecifikációk és becslési módszerek elemzésével igyekszik hozzásegíteni az olvasót az úgynevezett „border effect puzzle” megfejtéséhez.
\end{abstract}

Journal of Economic Literature (JEL) kódok: F14, F15

Kulcsszavak: határhatás, gravitációs modell, kereskedelem torzulása

\section{Bevezetés}

A XX. század második felében egyre inkább megszaporodó regionális kereskedelmi megállapodások, valamint az elmélyülő gazdasági és pénzügyi globalizáció az országhatárok gazdasági jelentőségének csökkenése felé mutatnak. Reich (2010) szerint rövidesen nem is lesz érdemes nemzetgazdaságokról beszélni, hiszen a termékek, a szolgáltatások, a technológia, a tőke határokat nem ismerve áramlanak a világban és válnak globálissá, megszüntetve az országhatárok gazdasági jelentőségét.

Jelen tanulmány - a határhatás-irodalom áttekintésén keresztül - némileg visszafogottabban közelíti meg a problémát, és Gilpin (2011) véleményéhez hasonlóan amellett érvel a határhatás irodalmának áttekintésével, hogy az országok kevésbé 
nyitottak, mint azt sokan gondolják, a nemzetközi piacok kevésbé integráltak, mint a - formális korlátokat figyelembe vevő, de egyéb súrlódásoktól mentes - modell alapján lenniük kellene.

McCallum (1995) például úttörő tanulmányában arra mutat rá, hogy 1988ban egy kanadai provincia átlagosan 22-szer többet kereskedett egy másik kanadai provinciával, mint egy hasonló jövedelmü és ugyanolyan távolságban lévő amerikai állammal, vagyis a belföldi kereskedelmet jelentős előnyben részesítette a nemzetközivel szemben. A jelenséget - amit Obstfeld és Rogoff (2001) a nemzetközi makroökonómia hat legnagyobb puzzle-jei között említ - határhatásként (border effect) definiálja a szerző, és hangsúlyozza, hogy a határok jelentősen befolyásolják a nemzetközi gazdasági kapcsolatokat.

Egy empirikus irodalmakat összegző tanulmány többféle rendezőelv alapján is összeállhat. A szerző haladhat kronológiai sorrendben, azaz évről évre bemutathatja a kutatók eredményeit, kezdve a legrégebbi - az adott alirodalmat indító - tanulmánnyal. Ez a cikk nem ragaszkodik teljesen ehhez az elvhez, bár kiindulási és viszonyítási alapként, értelemszerűen, McCallum (1995) úttörő tanulmányára hivatkozik. Irodalmak összegyüjtésének jó módszere lehet a térbeli csoportosítás, vagyis jelen esetben a határhatásra vonatkozó empirikus eredmények felbontása földrajzi régiónként. Érdekes lehet például összehasonlítani egymással az Európára és az Amerikai Egyesült Államokra kapott konkrét eredményeket, vagy éppen fejlettebb országcsoportra becsült értékeket összevetni fejlődő világbeli országok paramétereivel. A nélkül azonban, hogy tisztában lennénk a mögöttes logikai struktúrával, az eredmények eltérésének egyéb okaival (modellspecifikáció, becslés módszere, adatok forrása, elméleti háttér figyelembe vétele), félrevezető és nem valós következtetésekre juthatunk ilyen jellegü összehasonlításokkal. Ez a tanulmány éppen ezért - az idődimenziót és a térstruktúrát sem mellőzve - egy komplex és logikus áttekintést kíván adni a határhatás eddigi tudományos tanulmányozásáról, különös fókusszal a vizsgálatok technikai hátterére, azaz a különböző modellkiterjesztésekre és az ökonometriai problémákra. A törzsszövegben az egyes cikkek föként azon gondolatait mutatom be, amelyek hozzájárultak a határhatás-irodalom előrehaladásához, a teljesség kedvéért azonban a kutatásokban lefuttatott regressziók legfontosabb paraméterei a Melléklet 1. táblázatában is megtalálhatóak, időrendben összegyüjtve.

A problémakört az alábbi részegységek keretében elemzi a cikk: a második részben felvázolom az elméleti és módszertani keretet, vagyis a nemzetközi kereskedelem gravitációs modelljét, majd ezt követöen bemutatom az erre épülő empirikus irodalom föbb megállapításait, mérföldköveit, ökonometriai buktatóit. Az utolsó rész pedig összegzi a dolgozat megállapításait, kiértékeli a határhatás-irodalom aktuális helyzetét. 


\section{A határhatás és a gravitációs modell}

Egy súrlódásmentes világpiac - amely Reich (2010) szerint nem is tünik oly távolinak - adott országában az értékesített hazai termékek arányának meg kellene egyeznie a hazai termelés világtermelésben betöltött arányával (Balta-Delgado 2007; Yi 2010). Már Samuelson (1954) is megemlíti azonban, hogy a valóságban a fogyasztás torzulást mutathat a belföldi piacok felé, aminek két fő oka lehet: az országok közti jövedelemkülönbségek és az áruszállítás során jelentkező tranzakciós költségek. Az országhatár átlépésével felmerülő költségeket Olper és Raimondi (2008) három csoportba osztja: (1) kereskedelempolitikai eszközök, úgymint vámok és nem vámjellegü korlátozások, (2) kereskedelempolitikához nem köthető akadályok, úgymint fogyasztói preferenciákban meglévő torzulás, vagy információszerzéssel kapcsolatos költségek, valamint (3) az import és a hazai előállítású termékek közötti helyettesíthetőség mértéke. Mindezekből az következik, hogy a gazdasági kibocsátás és a kereskedelmi költségek kontrollálása mellett az országhatároknak nem kellene éreztetniük befolyásoló hatásukat a bilaterális kereskedelemre vonatkozólag. Másképp, egy tökéletesen integrált piacon egy ország gazdasági szereplőinek a belföldiekkel folytatott kereskedelme meg kellene egyezzen azzal a mennyiséggel, amennyit ezek a szereplők egy hasonló gazdasági méretű ország ugyanolyan távolságban lévő gazdasági szereplöivel kereskednek (Balta-Delgado 2007).

A probléma vizsgálatához a nemzetközi kereskedelmi áramlások vizsgálatának legnépszerúbb és legmegbízhatóbb - elméletileg is alátámasztott - empirikus módszeréhez, a gravitációs modellhez kell fordulnunk. Az alapgondolat, miszerint a newtoni elmélet átültethető a bilaterális kereskedelem vizsgálatára, a holland Tinbergen (1962), valamint a finn Pöyhönen (1963) kutatóktól származik. Bár egyikük sem nevezi nevén a modellt, egymástól függetlenül arra a megállapításra jutnak, hogy két tetszőleges ország között zajló áruforgalom $\left(T_{i j}\right)$ az országok jövedelmének ( $Y_{i}$ és $\left.Y_{j}\right)$ pozitív, a közöttük lévő távolságnak $\left(D_{i j}\right)$ viszont negatív függvénye ${ }^{1}$.

$$
T_{i j}=A Y_{i}^{\gamma} Y_{j}^{\delta} D_{i j}{ }^{\theta}
$$

A modell gyorsan rendkívüli népszerűségre tett szert az empirikus közgazdászok körében, hiszen annak ellenére, hogy hiányzott a közgazdasági elméleti alap, meglehetösen jó illeszkedést mutatott a valós adatokhoz. Az első elméleti levezetés Anderson (1979) nevéhez köthető, aki nemzetközi fogyasztási keretrendszerben ad mikroökonómiai alapot a modellnek. A szerző - tökéletes versenyt, identikus és homotetikus preferenciákat valamint származási ország szerint differenciált

1 Tehát az (1) egyenletben $\gamma>0, \delta>0$ és $\theta<0$. 
termékeket ${ }^{2}$ feltételezve - jut el az (1) egyenlethez hasonló, népességgel kibővített gravitációs modellhez. A szállítási költségeket egyébként - Samuelson (1954) „jéghegy” modelljét alapul véve - vonja be a modellbe. E szerint az áruk értékének egy része szállítás közben elveszik, hiszen minél messzebb van két ország egymástól, annál több költségtényező merülhet föl szállítás közben, azaz annál kisebb lesz a kettejük között realizálódott kereskedelem nagysága.

Később több elméleti levezetés is született, bizonyítva a modell közgazdasági hitelességét. Krugman (1980) és Bergstrand $(1985,1989)$ - az Új Kereskedelemelmélet fő képviselői - a növekvő skálahozadékra, a monopóliumokra helyezik a hangsúlyt, a gravitációs modellt a monopolisztikus versenyből vezetik le, kapcsolatot teremtve a külföldi és belföldi áruk relatív fogyasztása, valamint a szállítási költségek között. Deardorff (1998) szerint - az előzőeken kívül - a Heckscher-Ohlin modellen alapuló általános egyensúlyból is származtatható a gravitációs modell, amikor a kétoldalú kereskedelem a relatív tényezöellátottságon alapul. Eaton és Kortum (2002) végezetül arra is rámutat, hogy egy ricardói keretrendszerben is értelmezhető a gravitációs összefüggés az országok közöttt.

Anderson és van Wincoop (2003) a gravitációs modellel foglalkozó irodalom talán legtöbbet hivatkozott tanulmányában felhívják a figyelmet az árak fontosságára. Rávilágítanak, hogy két tetszőleges ország között a kereskedelem nemcsak az abszolút, hanem a relatív kereskedelmi költségektől is függ, aminek figyelmen kívül hagyása elméletileg inkonzisztens modellspecifikációkhoz és torzított eredményekhez vezet. Elméleti levezetésük egy-egy komplex, közvetlenül nem mérhető ártényezőt is tartalmaz (multilateral trade resistance term ${ }^{3}$ ), ami ismert és mérhető költségtényezők nem-lineáris egyenletrendszereként írható fel. Wei (1996), Helliwell (1998) valamint Hellivell és Verdier (2001) is próbálkoznak megoldást találni az árakkal kapcsolatos problémára, de az alternatív kereskedelmi partnerektől való - jövedelemmel súlyozott - átlagos távolságként meghatározott, azaz relatív távoliságként is értelmezhető változóik (remoteness) elméletileg nem megalapozottak. Anderson és van Wincoop (2003) szerint tehát a gravitációs modell egyenlete az alábbi formát ölti:

$$
x_{i j}=\frac{Y_{i} Y_{j}}{Y^{w}}\left(\frac{t_{i j}}{P_{i} P_{j}}\right)^{1-\sigma}
$$

2 A nemzetenkénti termékdifferenciálódást egyébként Armington-feltételként jegyzi az irodalom, Armington (1969) alapján.

3 Talán a leghủbben multilaterális, vagyis a világ összes országa felé jelentkező kereskedelmi akadályokként fordítható. Ezek a komplex árindexmutatók az összes bilaterális kereskedelmi költségnek és jövedelmeknek a függvényei. 
ahol $x_{i j}$ az $i$ országból $j$ országba tartó áruexport nagysága. $Y_{i}, Y_{j}$ és $Y^{w}$ rendre $i$ ország, $j$ ország és a világ nominális jövedelmét jelentik. $\sigma$ az áruk közötti helyettesítési rugalmasságot takarja. $P_{i}$ és $P_{j}$ jelöli a multilaterális kereskedelemi akadályokat, melyekkel $i$-nek és $j$-nek szembe kell néznie az egymással folytatott kereskedelem során. Minél nagyobb multilaterális kereskedelmi akadályokkal kell szembenéznie $i$, illetve $j$ országnak, annál nagyobb kereskedelem realizálódik kettejük között, hiszen - relatíve - annál kisebb áron tudnak hozzájutni egymás termékeihez. Végezetül $t_{i j}$ a szállítás során felmerülő, bilaterális tranzakciós költségeket foglalja magába, ami további tényezőkre bontható, úgymint távolság, közös szárazföldi határ, kulturális/ nyelvi hasonlóság, közös valuta, regionális kereskedelmi megállapodások, illetve jelen cikk tárgya - a határhatás.

Anderson és van Wincoop (2003) elméletileg alátámasztott modellje - eredeti formájában - nem-lineáris programozással becsülhető csak meg. A bonyolult eljárást elkerülendö, Rose és van Wincoop (2001), valamint Feenstra (2002) egy alternatív módszert javasol a multilaterális kereskedelmi akadályok kontrollálására, mégpedig dummy változók bevezetését a kiinduló és célországra vonatkozóan ${ }^{4}$. Ezzel a kiterjesztéssel egy olyan - az elmélettel konzisztens - egyenlet adódik, melyre torzításmentes eredményeket ad az OLS módszer eredményül.

Baier és Bergstrand (2009) tovább finomítja Anderson és van Wincoop (2003) elméleti modelljét, mégpedig abból a célból, hogy a multilaterális kereskedelmi akadályok explicit módon való szerepeltetése mellett is becsülhető legyen a modell a klasszikus legkisebb négyzetek módszerével. Egy log-lineáris, elsőrendű Taylorsorfejtéssel olyan alakra alakítja át a szerzőpáros Andersonék egyenletét, ami OLS módszerrel is konzisztens, torzításmentes, valamint az eredeti Anderson és van Wincoop (2003)-féle becsléssel ekvivalens paramétereket eredményez.

A nemzetközi közgazdaságtannal foglalkozó kutatók kedvelt empirikus eszköze lett a gravitációs modell, melynek köszönhetően meglehetősen nagy magyarázó erővel becsülhetőek meg jelentős kereskedelempolitikai döntések, gazdasági intézmények kereskedelemre kifejtett hatásai. McCallum (1995) - úttörőnek számító munkájában - azonban egy egészen új szempontból közelíti meg a modellt azzal, hogy beemeli az országon belüli kereskedelmi áramlásokat is a vizsgálatába. A belföldi piacot mint elméletileg - tökéletesen integrált egységet viszonyítási alapnak véve az ő módszerével megállapítható a nemzetközi árupiacok töredezettségének foka, vagy másképp az, hogy egy ország kereskedelme milyen mértékủ torzulást mutat a belföldi partnerek felé. 10 kanadai provinciára és 30 amerikai államra kiterjedő vizsgálatában az alábbi logaritmizált regressziós egyenletet (3) alkalmazta McCallum (1995):

4 Anderson és van Wincoop (2003) eredményei már 2001-ben megjelentek working paper formájában a National Bureau of Economic Researchnél, ezért tudtak 2001-ben és 2002-ben reflektálni rá. 


$$
\ln X_{i j}=\beta_{0}+\beta_{1} \ln Y_{i}+\beta_{2} \ln Y_{j}+\beta_{3} \ln D_{i j}+\beta_{4} B O R D E R_{i j}+u_{i j}
$$

ahol $B O R D E R_{i j}$ egy olyan bináris változó, aminek értéke 1, ha a kereskedelmi ügyletek országhatáron belül zajlanak le (azaz i és j egyazon országot jelenti), és 0 , amennyiben nemzetközi árumozgásokról van szó. A további változók megegyeznek az (1), illetve (2) egyenletben definiált változókkal. A $B O R D E R_{i j}$ dummy paramétere adja meg a határhatás nagyságát, vagyis azt a túlzottan nagy kereskedelmi volument, ami egy országon belül figyelhető meg ahhoz a „normális” forgalomhoz képest, amit a gravitációs modell alapváltozóival (jövedelmek és távolság) becsülnénk (Head-Mayer 2002).

Meg kell jegyezni, hogy ugyan a határhatás-vizsgálat legjellemzöbb eszköze a gravitációs modell, egy talán kevésbé népszerübb irány is kialakult Engel és Rogers (1996) munkássága nyomán, mely szerint a határok kereskedelmet torzító szerepe az egy ár törvényének (LOOP) meg nem valósulásával is kimutatható mikroszinten. Horváth és szerzőtársai (2008), valamint Pásztor (2014) ezzel a módszerrel elemzi Magyarország és a szomszédjai között érződő határhatást.

\section{Empirikus eredmények a határhatásról}

McCallum (1995) határhatásra vonatkozó eredménye első hallásra meglehetősen túlzónak tünhet. 1988-as kanadai és amerikai adatokon - a klasszikus legkisebb négyzetek (OLS) módszerével - lefutatott keresztmetszeti vizsgálata szerint ugyanis egy kanadai provincia 22-szer többet kereskedett belföldön, ceteris paribus. Vagyis a hazai kereskedelmet meglehetösen nagy előnyben részesítette a nemzetközivel szemben. A vizsgálat eredménye főleg annak tudatában meglepö, hogy a két ország egy szabadkereskedelmi egyezmény megkötése előtt állt, ráadásul, a Kanada-USA határt a kereskedelmet kevésbé korlátozó határok között tartották akkoriban számon világszerte.

\subsection{A határhatás nagyságát befolyásoló tényezők}

Az egész határhatás-irodalom tulajdonképpen McCallum (1995) meglepőnek tünő eredményét igyekszik cáfolni, illetve logikusan megmagyarázni. Anderson és Smith (1999a, 1999b) például finomítják McCallum modelljét, kiterjesztve a magyarázó változók körét a közös szárazföldi határral és az egy főre jutó GDP-vel5. Kibővített

5 A gazdasági fejlettség egyébként, ami relatív tényezőellátottságként (tőke/munka) is felfogható, a monopolisztikus versenyen, valamint a Heckscher-Ohlin modellen alapuló gravitációs modelleknél tünik fel. 
gravitációs modelljük 1988-ra már csak 15,2-szeres, 1990-re pedig 14,3-szeres átlagos határhatást jelez a kanadai provinciák vonatkozásában.

Anderson és van Wincoop (2003) is McCallum (1995) tanulmányából indul ki és fogalmazza meg a multilaterális kereskedelmi akadályok fontosságát, és empirikusan is igazolja, hogy ezeknek a változóknak a kihagyása - lévén, hogy a távolsággal és az országhatárokkal felmerülő tranzakciós költségekkel korrelálnak - jelentősen torzítja a határhatás paraméterét felfelé. 1993-as adatokkal csak fele akkora határhatást mutat ki, mint McCallum (1995). Ráadásul, mivel a határhatás egy relatív érték, azaz a belföldi kereskedelmet viszonyítja a nemzetközihez, az eredményeket az is befolyásolja, hogy a kanadai provinciák, vagy éppen az amerikai állomok felöl értelmezzük. Elöbbi esetén nagyságrendileg magasabb értéket kapnak a szerzők.

Feenstra (2002) szintén rávilágít az árindexek fontosságára, viszont a kiinduló és céltérségre bevezetett fix hatásokkal demonstrálja, hogy OLS-szel is lehet elméletileg konzisztens eredményekre jutni a gravitációs modell paramétereit illetően. 4,7es átlagos határhatás-értékével alátámasztja Anderson és van Wincoop (2003) azon felvetését, hogy az amerikai államok kisebb határhatással szembesülnek Kanada irányába, mint a kanadai provinciák az USA felé.

Yi (2010) szerint azonban a világgazdaságnak egy fontos jellemzője még Anderson és van Wincoop (2003) figyelmét is elkerülte, aminek nyomán ők is felülbecsülik a határhatás nagyságát a Kanada-USA relációban, és ez nem más, mint a nemzetközi szinten jelentkező vertikális iparági specializáció. Állítása szerint ugyanis más a végső feldolgozottsági fokú és az alacsonyabb feldolgozottsági fokú termékek helyettesítési rugalmassága. Egy olyan régió esetén pedig (USA-Kanada), ahol a nemzetközi árukereskedelem hozzávetőlegesen egyharmad része az autóiparhoz köthetö, vagyis egy olyan iparághoz, ahol gyakori a vertikális nemzetközi munkamegosztás, ezeknek a jellemzőknek a mellőzése felfelé torzítja a határhatás paraméterét. Több fázisú termelésen alapuló modelljéből kalibrált kereskedelmi adatokkal Yi (2010) csak 9,2-es határhatást mutat ki Kanada és az USA között. Evans (2003) is a helyettesítési rugalmasságok és az árkülönbségek fontosságára, illetve ezeknek a határhatásra kifejtett jelentőségére hívja fel a figyelmet, és próbálja megfejteni a határhatás közgazdasági relevanciáját. Vizsgálata szerint minél inkább differenciált egy termék, azaz minél kisebb a helyettesítési rugalmassága, a határhatás annál nagyobb lesz. Többféleképpen specifikált regressziói azt is elörevetítik, hogy a határok torzító hatását sokkal kisebb részben magyarázzák a - jólét és jövedelem-eloszlás befolyásolását célzó - kereskedelempolitikai intézkedések, mint azt az irodalom nagy része állítja. Arra is rámutat továbbá Evans (2003), hogy Anderson és van Wincoop, valamint McCallum határhatásának közel 40\%-a azzal magyarázható, hogy modelljükben az egyfázisú termelésből indulnak ki.

A nemzetközi piacokon meglévő határhatásról kialakuló képet nemcsak a korábban már említett - kihagyott változók, hanem a mérési hibák okozta torzítás is árnyalhatja. A legélénkebb vitát a távolságok pontos meghatározása váltotta ki a 
kutatók körében. Több kísérlet is született a fogyasztók és a termelök közötti átlagos távolság definiálására. A gravitációs modellel dolgozó empirikus közgazdászoknak alapvetően két ország földrajzi távolságát kell meghatározniuk, amit leggyakrabban a valóságtól némileg elrugaszkodva és a gazdaság térbeliségét figyelmen kívül hagyva - két föváros vagy két gazdasági központ távolságaként adnak meg. Wolf (2000), Chen (2004), valamint Head és Mayer (2002) azonban több gazdaságilag jelentös várost is bevon vizsgálatába, és bilaterális távolságon azok népességgel súlyozott átlagos távolságát érti.

A határhatást kutatóknak azonban nemcsak az országok közötti, hanem az országokon belüli kereskedelmi távolságra is szükségük van. A hazai fogyasztók és hazai termelők között meglévő átlagos távolság megbecslését alapvetően három csoportba érdemes sorolni. Az első csoportba tartozik az úgynevezett legközelebbi szomszéd módszere. Wei (1996) szerint jól leírhatja a belföldre jellemző távolságot a legközelebbi szárazföldi, szomszédos országtól vett távolság negyed része, míg Wolf (2000) a bilaterális távolság felét használja regressziójában. A módszer könnyen támadható, hiszen például Franciaországra kisebb érték adódik, mint Portugáliára, ami a racionalitásnak erőteljesen ellentmond.

A területalapú megközelítés már elméletileg jobban alátámasztott. E szerint az országokat egy hipotetikus körrel azonosítják, melynek középpontjába összpontosul a termelés, a fogyasztók pedig valamilyen rendezőelv alapján helyezkednek el annak területén. Attól függően, hogy a fogyasztók mennyire koncentrálódnak a gazdaság központjához, azaz a kör középpontjához, a belföldre jellemző kereskedelemi távolságot a feltételezett kör sugarának bizonyos hányada adja. Leamer (1997) és Nitsch (2000) a sugár egészét, Head és Mayer (2000) annak kétharmadát, Rich (1980) a felét, Redding és Venables (2000) pedig az egyharmad részét tekinti a pontos belföldi távolságnak.

A harmadik csoportba pedig a valósághoz leginkább közelítő módszerek tartoznak, melyek lényege, hogy számításba veszik az összes gazdaságilag jelentős város egymástól vett távolságát. Wolf (2000), Helliwell és Verdier (2001), valamint Chen (2004) súlyozott számtani átlagos távolságként definiálja a belföldi távolságokat, míg Head és Mayer (2002) algebrai és geometriai úton is bebizonyítja, hogy egy országban a termelők és fogyasztók között lévő tényleges átlagos távolságot a gazdaságilag jelentős városok népességgel súlyozott harmonikus átlagos távolsága adja. A szerzőpáros ki is emeli, mekkora torzítást okoz a távolságok mérésének hibája a határhatás vonatkozásában.

Természetesen nemcsak az észak-amerikai kontinensen születtek elemzések a határhatásról, hanem a világ számos más pontján is. McCallum (1995) módszertanát azonban nem is annyira kézenfekvő átültetni más országokra, mint azt gondolnánk. Észak-Amerikán kívül ugyanis nem igazán állnak rendelkezésre olyan részletes, 
regionális szintű árukereskedelmi statisztikák, mint az Egyesült Államokban ${ }^{6}$, ami megakadályozza a belföldi kereskedelem explicit beemelését a gravitációs modellbe. Wei (1996) azonban egy olyan közelítő eljárást javasol, amivel megbecsülhető a belföldi kereskedelem volumene, valamint lemérhető a határhatás nagysága olyan országoknál is, ahol nem tartanak nyilván megfelelően részletes árukereskedelmi statisztikákat. Módszerének alapfeltevése szerint egy ország a megtermelt áruit belföldi és külföldi vevők között osztja szét. Ekkor a belföldi kereskedelem nagyságának jó mérőszáma lehet, ha kivonjuk a világ összes országába tartó áruexport értékét a teljes árutermelésből. Ehhez előbb ki kell szürni a szolgáltatásokat és egyéb összetevőket a GDP-ből, majd át kell alakítani a hozzáadott érték alapon számított termelési értéket szállítási értéken vett termeléssé. Ezután már elvégezhető a kivonás: a teljes árutermelés és a teljes áruexport különbsége adja a belföldi kereskedelem nagyságát. Wei (1996) - módszertani újításának köszönhetően - egy átlagos OECD-országra is bizonyítani tudja a határhatás létezését.

Érdemes közelebbről is megvizsgálni, mi okozhatja még a határhatás létezését az országok között, azaz milyen egyéb tényezőkkel és milyen mértékben lehet megmagyaráznia hazaikereskedelem preferálását. A nemzetközigazdaságikapcsolatok elmélyülését megnehezíthetik például az országok között meglévő kulturális és nyelvi különbségek. Az országhatárok átlépésével - különösen az európai kontinensen - más szokásokkal, a hazaitól merőben eltérő attitűdökkel, ízlésekkel, idegen nyelven beszélő partnerekkel találhatják szembe magukat a vállalatok. Mindezek tudatában indokolt lehet a jobban ismert belföldi kereskedelmi partnerek preferálása. Wei (1996), Nitsch (2000), valamint Head és Mayer $(2000,2002)$ - a regresszió független változói között definiálnak egy dummy változót a közös nyelvre vonatkozóan, ami 1-et vesz fel abban az estben, ha a két vizsgált ország azonos nyelven beszél, és 0 -át minden más esetben. Ennek köszönhetően az OECD, valamint az Európai Közösség országainak esetében McCallum (1995) értékénél nagyságrendileg kisebb torzulást mutatnak ki a belföldi piacok felé.

A gazdasági integrációk egyik legnagyobb kihívást jelentő mérföldköve a monetáris unió bevezetése, melytől dinamikus kereskedelem-bővülést és gazdasági növekedést várnak legtöbbször az érintett országok vezetői. Rose (2000) sokakat megdöbbent, amikor arra a megállapításra jut, hogy két ország 3-szor többet kereskedik egymással abban az esetben, ha közös fizetőeszközt használnak, ceteris paribus. Az eltérö valuták miatt felmerülő tranzakciós és kockázati költségek szintén óvatosságra intik a vállalatokat a külpiacra lépéssel kapcsolatban, és ezzel egyidejüleg hozzájárulhatnak

6 Okubo (2003, 2004), Gil-Pareja és szerzőtársai (2004), valamint Llano-Verduras és szerzötársai (2011) McCallumhoz hasonlóan regionális kereskedelmi adatok segítségével becslik meg a Japánra, illetve Spanyolországra jellemző határhatás nagyságát. Xing és Li (2011) szintén egyedi áruforgalmi statisztikák segítségével mutatnak rá egy meglehetősen nagymértékű nemzetközi integráltságra a kínai provinciákra vonatkozóan. 
a belföldi kereskedelmi szálak megerősítéséhez. A valuta kontrollálása tehát tovább csökkentheti a határhatás paraméterét. Helble (2006) - regionális szállítási adatokon alapuló modelljében - a közös valutára vonatkozó dummy bevonásával becsüli meg a határhatás nagyságát Németország és Franciaország vonatkozásában.

McCallum (1995) olvasatában tehát a határhatás változója minden kereskedelmet korlátozó tényezőt magába foglal a távolságon kívül, vagyis a Solow maradékhoz (Solow 1957) hasonlatosan értelmezhető. Ekkor a belföldi kereskedelem preferálása a határátlépéssel felmerülő költségtényezőkkel (vámok, nyelvi különbségek, eltérő valuta, szomszédság, árak) részben magyarázható. A fentebb ismertetett tanulmányok azonban azt demonstrálják, hogy hiába szerepel minél több - a határhatás kialakulásában szerepet játszó - akadályozó tényező konkrétan a magyarázó változók között, az országhatár továbbra is szignifikánsan korlátozza a kereskedelmet két ország között, ami már indokolatlannak tűnhet. Felmerül a kérdés, hogy abban az esetben, ha sikerül minden befolyásoló tényezőt kontrollálni, továbbra is szignifikánsan különbözni fog-e nullától az országhatár dummyjának paramétere. Amennyiben igen, akkor kijelenthető, hogy a vállalatok indokolatlanul részesítik előnyben a belföldi partnereket a külföldiekkel szemben. Ekkor válik a határhatás kérdésköre a nemzetközi gazdaságtan egyik igazán nagy problematikájává. Suvankulov (2015) például igyekszik az összes olyan megfigyelhetö tényezöt kontrollálni egyenletében, ami korábbi tanulmányoknál felmerült nemzetközi kereskedelmet alakító tényezöként. Kiterjesztett gravitációs modelljébe olyan magyarázó változókat emel be, mint árfolyam, közvetlen külföldi tőkebefektetések, közös nyelv, szomszédság, gyarmati múlt, vámok, WTO tagság, nem vámjellegü eszközök, valamint relatív távoliság. A szerző még ilyen sok magyarázó változó számbavétele után is arra jut, hogy a kanadai provinciák kereskedelme torzulást mutat a belföldi piac felé, aminek mértéke 4,8-szeres. Azt is kiemeli azonban, hogy a G20, valamint az EU országai felé még ennél is jelentősebb határhatás mutatkozik. Mindezek alapján mindenesetre úgy tünik, a határhatás mibenlétének bizonyos részét nehezen vagy egyáltalán nem lehet megmagyarázni.

A belföldi kereskedelem indokolatlan vagy túlzott preferálása egy olyan integrált piacon tesztelhető legegyszerübben, amit - sok szempontból - homogén egységek alkotnak, és így a tranzakciós költségeknek nagy része föl sem merül akadályozó tényezőként a nemzetközi kereskedelem során. A kritériumoknak leginkább megfelelő térség az Amerikai Egyesült Államok belső piaca lehet. A határhatáskutatás módszertana, valamint a részletes államszintü statisztikák lehetőséget is adnak a kutatók számára, hogy megvizsgálják, kimutatható-e valamiféle torzulás az USA államainak kereskedelemében ${ }^{7}$. Figyelembe véve azt, hogy meglehetősen homogén

7 Az amerikai Commodity Flow Survey 1993-ban, 1997-ben, 2002-ben és 2007-ben közölt eddig megfelelően részletes, államszintü árukereskedelmi adatokat, melyek segítségével megbecsülhető a határhatás nagysága az USA belső piacán is. 
államok gazdasági és politikai szövetségéről van szó, ahol vám és nem vámjellegü korlátozások, valutaátváltással, nyelvvel és kultúrával kapcsolatos akadályok nem hátráltatják a kereskedelmet, egy átlag amerikai államnak - elméletileg - nem kellene preferálnia az államhatárokon belüli kereskedelmet. Az empíria azonban ellentmond a feltételezéseknek. Wolf (2000), Head és Mayer (2002), valamint Millimet és Osang (2007) is azt igazolják, hogy az amerikai államok között is megfigyelhető a határhatás jelensége. Számításaik szerint egy átlagos amerikai állam 1993-ban 3-5-ször annyit, 1997-ben viszont majdnem 6-szor annyit kereskedett saját határain belül, mint egy másik állammal, figyelembe véve a távolságokat, a jövedelmeket és a közös, szárazföldi államhatárokat. Az okokat többek között arra próbálják visszavezethetni a kutatók, hogy a vállalatok - a szállítási költségek minimalizálása végett - inkább áthelyezték termelésük bizonyos fázisait egy másik államba, ahelyett, hogy határon átnyúló kereskedelmet folytattak volna. Hillberry és Hummels (2003) azonban három fontos tényezőt kiemelnek, ami miatt Wolf (2000) túlbecsüli az államok közötti határhatás nagyságát. Egyrészt felhívják a figyelmet arra, hogy a nagykereskedelmi áruforgalom nagy része nem jár együtt az államhatárok átlépésével, ezért érdemes kiszürni őket a vizsgált adatokból. Másrészt - miképp Rose és van Wincoop (2001), valamint Feenstra (2002) - államspecifikus fix hatásokkal kontrolálják az árak és az egyéb államszintű sajátosságok hatását. Harmadrészt - akárcsak Head és Mayer (2002) - óva intenek a különféle alternatív távolságbecslésektől, és az áruszállítások során regisztrált fuvarozási távolságokat használják magyarázó változóként.

Coughlin és Novy (2009) egyszerre vizsgálják meg az államok közötti, vagyis az USA-n belüli, illetve az államok és más országok közötti, azaz a nemzetközi határhatást. Arra az érdekes megállapításra jutnak, hogy a belföldi határhatás nagyobb a nemzetközinél, vagyis az amerikai cégek az államon belüli kereskedelmet nagyobb előnyben részesítik az államok közötti kereskedelemmel szemben, mint az államok közöttit a nemzetközivel szemben. 1993-ban az államok közötti határhatás 7,7-szeres, míg a nemzetközi határhatás csak 3,5-szeres értéket mutatott.

Az eddig leírtak alapján - bár nehéz lenne általános képet festeni a világpiacról, illetve annak egyes régióiról a határhatás nagyságát illetően - úgy tünik, hogy a hazai kereskedelmi partnerek preferálása túlzott, vagyis annak mértéke csak részben magyarázható formális tényezőkkel.

\subsection{A határhatás vizsgálata időben - a panelspecifikációk problematikái}

A határhatás elemzési módszere nemcsak arra vonatkozólag lehet hasznos, hogy meghatározzuk a belföldi kereskedelem preferálásnak mértékét egy adott időpontban, hanem segítségünkre lehet abban is, hogy kiértékeljük egy-egy nemzetközi árupiac fejlődési, avagy integrálódási folyamatát. A mutató időbeli alakulásából ugyanis következtetni tudunk arra, hogyan mélyülnek el, vagy éppen lazulnak fel a nemzetközi kereskedelmi kapcsolatok, miként gyengül, vagy éppen erősödik az országhatárok 
- gazdasági kapcsolatokat befolyásoló - szerepe. Helliwell $(1996,1998)$ például - a határhatás időbeli alakulásával - empirikusan támasztja alá az USA és Kanada között megkötött szabadkereskedelmi egyezmény integráló hatását. A szerző 1988ra McCallumhoz (1995) hasonló eredményt kap. A határhatás nagysága 1996-ra azonban 11,4-re csökken, mely szerint egy kanadai provincia - az adott évben már „csak” 11,4-szer többet kereskedik egy másik kanadai provinciával, mint egy amerikai állammal, figyelembe véve a regionális termelési és távolsági adatokat. Head és Mayer (2000) az Európai Közösség országaiban is kimutatja a határhatás időbeli csökkenését. Keresztmetszeti vizsgálatukkal bizonyítani tudják az árupiacok egyre mélyülő integrációját 1979 és 1990 között. Chen (2004) - egyetlen évre fókuszálva - figyelemreméltó megállapításra jut. 1996-ban - az Európai Unióhoz egy évvel korábban csatlakozott - Finnország nagyságrendekkel nagyobb torzulást mutat a hazai piac felé, mint Németország vagy éppen az Egyesült Királyság. Márkus (2017) pedig a Visegrádi négyek kereskedelmében mutat rá egy folyamatos fejlődésre az 1995-2011-es periódusban. Összességében az európai országokról elmondható, hogy az uniós tagságukat megelőzően, illetve annak kezdetén külpiacra lépő vállalataik még jelentős határhatással szembesültek, ami azonban az évek folyamán, a mélyülő integráció jeleként fokozatosan csökkenni tudott.

$\mathrm{Az}$ idődimenzió bevezetése, valamint a modern ökonometriai módszerek térnyerése fokozatosan megkövetelte, hogy a keresztmetszeti vizsgálatokat felváltsák a panelmódszerek. Az ökonometrikusok általában kétféle technikát alkalmaznak a paneladatok tulajdonságaiból adódó korrelációs probléma kezelésére: rögzített vagy véletlen hatások bevezetését. A gravitációs modellt alkalmazó kutatások során a Hausmann teszt rendre a fix hatású becslést javasolja a véltetlen hatással szemben. A rögzített hatású regressziós modellben idö- és egyénspecifikus dummy változók szerepelnek a magyarázó változók között. Az időegységre vonatkozó bináris változó magába foglal minden olyan - nehezen mérhető, a kereskedelmi kapcsolatokat mégis befolyásoló - tényezőt, ami időben változik, de az egyéneket hasonlóan érinti (például: világgazdasági sokkok). Az egyénekre - a gravitációs modell esetén országpárokra - vonatkozó dummyk pedig minden olyan tényezőt reprezentálnak, ami időben állandó, viszont egyénenként különbözik (például: speciális bilaterális kapcsolat). A határhatás-kutatás azonban különleges fix hatású specifikációt követel meg, hiszen az egyénspecifikus dummy változó becsült paramétere tartalmazná az időben állandó országhatár kereskedelemre kifejtett hatását is. Pacchioli (2011) ezért Mátyás (1997) ötletét hasznosítva becsül határhatást paneladatokon. Az országpárok helyett külön értelmez dummy változókat az exportáló és az importáló országra. Így az átlagos határhatás paramétere becsülhetővé válik, hiszen egyik bináris változó sem fedi le annak hatását. Empirikus vizsgálatában a 14 európai uniós ország közötti, valamint amerikai államok közötti belső piac integráltsági fokát hasonlítja egymáshoz az 1996-2002-es időszakban. A szerző arra a megállapításra jut, hogy az EU árupiaca háromszor annyira töredezett, mint az Amerikai Egyesült Államoké. 
A határhatás szempontjából indokolhatónak tünhetnek ugyan az exportőrre és az importőrre szétválasztott rögzített hatások, Cheng és Wall (2005) empirikus példán keresztül mégis azt bizonyítja, hogy a klasszikus specifikáció statisztikailag jobban teljesít, és ezért mindenképpen preferált lehet Mátyás (1997) specifikációjával szemben. Baldwin és Taglioni (2006) szintén az országpárokra értelmezett fix hatások relevanciáját hangsúlyozza, hiszen ezek felelnek a párok közötti heterogenitás kontrollálásáért. Másképpen kereskedik például Magyarország Romániával, mint Németországgal, sőt másképpen kereskedik Magyarország Németországgal, mint Németország Magyarországgal, de szintén más elvek érvényesülnek két magyar vállalat közötti kereskedelemben. A különbözöséget pedig nem csak konkrétan megfigyelhető és explicit bevonható magyarázó tényezők okozzák, hanem nem megfigyelhető jellemzők is, melyek figyelembevétele kulcskérdés lehet az eredmények szempontjából.

Baldwin és Taglioni (2006) ugyanakkor kiemeli az ország-dummyk létjogosultságát is, hiszen azok foglalják magukba a világ országaival szemben felmerülő (multilaterális) kereskedelmi akadályok hatását. Szerintük az a megfelelő gravitációs modellspecifikáció, ahol évenként értelmezett ország-dummykkal együtt időben állandó országpár-hatások szerepelnek kontrolláló tényezőkként. Igaz, Cheng és Wall (2005), valamint Baldwin és Taglioni (2006) fókuszában nem a határhatás szerepel, eredményeik mégis útmutatóként szolgálhatnak a közgazdaságilag és statisztikailag is megfelelő, torzításmentes gravitációs modellspecifikáció összeállításában.

Ahhoz, hogy a klasszikus fix hatású keretrendszerben becsülhető legyen a belföldi piacok iránt mutatott torzulás mértéke, évekre lebontott határváltozók definiálására van szükség, ahogyan azt Andresen (2010) és Márkus (2017) is demonstrálja. Ez esetben azonban Baldwin és Taglioni (2006) óvatosságra int az eredmények interpretálását illetően ${ }^{8}$. A határhatás-változó paramétere - ami a megszokottól eltérően egyébként Andresen (2010) és Márkus (2017) esetében is többször negatív tartományba lép ekkor már csak a változó időbeli alakulásának hatását tükrözi, hiszen az országhatár és a kereskedelem között meglévő keresztmetszeti kapcsolat továbbra is a fix hatásban ütközik ki. A panelspecifikációk tanulsága mindenesetre az lehet, hogy a határhatás nagy része - és talán a korábban meg nem magyarázott fele - az országpárok között fennálló, nem megfigyelhetö heterogenitással függ össze.

\subsection{A logaritmikus transzformáció okozta torzulás}

Végezetül érdemes szót ejteni a lineáris modellspecifikáció hátrányáról. A gravitációs modellel foglalkozó empirikus irodalom sokáig természetesnek vélte az elméletből levezetett és szorzatalakban megjelenő modell logaritmizálását annak érdekében,

8 A szerzők az euró kereskedelmet befolyásoló hatását vizsgálják ugyan, de a fix hatásra vonatkozó következtetésük érvényes a határhatás-becslés esetére is. 
hogy egy egyszerüen megbecsülhető lineáris egyenlet adódjon. A (3) egyenlethez hasonló képletekre ugyanis a legkisebb négyzetek módszere (OLS) konzisztens, torzítatlan és hatásos becslést adhat eredményül. Santos Silva és Tenreyro (2006) azonban bebizonyítja, hogy a logaritmikus transzformációt követően - az úgynevezett Jenseni egyenlőtlenség9 miatt - az eltérésváltozók az esetek legnagyobb részében heteroszkedasztikusak lesznek, és így a legkisebb négyzetek módszere inkonzisztens becslést ad. A szerzőpáros szerint érdemes a gravitációs modellt szorzatalakban hagyni, és paramétereit az úgynevezett PPML (Poisson pseudo-maximum likelihood) becslőfüggvénnyel megbecsülni. Suvankulov (2015) például ezzel a módszerrel számítja újra a Kanada-USA határhatást a 2001-2010-es időszakra, és a McCallumféle alapspecifikációval bizonyítja, hogy pusztán a becslési módszer megváltoztatása 1/3-ával csökkenti a határok torzító hatását.

A PPML módszer nagy előnye még azis, hogy a - potenciálisan fontosinformációkat rejtő - zéró kereskedelmi forgalmat is kezelni tudja, azaz azok a megfigyelések is bevonhatóak a mintába, amelyeknél a bilaterális kereskedelmi forgalom valamilyen okból hiányzik, vagy nullára kerekített értékkel bír. Így elkerülhetővé válik az a torzítás, ami a kiegyensúlyozatlan panel vagy éppen az önkényesen megválasztott 0-tól különböző - exportértékek miatt következne be (Santos Silva-Tenreyro 2006).

Olper és Raimondi (2008), valamint Llano Verduras és szerzötársai (2011) szintén PPML becsléssel elemzik az árupiacok töredezettségét, előbbi páros az OECD-országok közötti agrárpiacok vonatkozásában, míg utóbbi szerzők a spanyol provinciák európai kereskedelmében. Érzékenységi vizsgálataikban - a Santos Silva-Tenreyro pároshoz hasonlóan - nyomatékosítják, hogy a módszer torzításmentes paraméterbecsléseket eredményez.

A brazil szerzőpáros módszertani újításától ösztönözve, Dias (2011) is felülvizsgálja McCallum (1995) nevezetes eredményeit. A szerző PPML becslése szerint a Kanada és az USA között húzódó határ 1988-ban durván 40\%-kal kevésbé akadályozta a nemzetközi kereskedelmi áramlásokat, mint ahogy azt McCallum (1995) becsülte. Sőt, egy sokkal merészebb kijelentést is tesz Dias (2011) a tanulmányában, amikor egy alternatív modellspecifikációt használ. Állítása szerint McCallum puzzle-jének nem is kellene léteznie abban a formájában, hiszen a határhatás legnagyobb részét nem politikai akadályok okozzák, hanem az a tény, hogy a távolság nem egyformán befolyásolja a kereskedelmet belföldi és nemzetközi viszonylatban.

9 Egy véletlen változó logaritmusának várható értéke nem egyenlő a változó várható értékének logaritmusával. 


\section{Konklúzió}

A tanulmány a nemzetközi makroökonómia egyik nagy rejtélyével, a határhatással (border effect), azaz a belföldi kereskedelem indokolt és túlzott preferálásával foglalkozik. A problémakör - lévén, hogy a nemzetközi piacok töredezettségét jellemzi - Magyarország és az Európai Unió szempontjából is aktuális és releváns kérdéseket vethet fel. A cikk - azon túl, hogy bemutatta a világ különböző pontjait vizsgáló empirikus eredményeket - sorra vette azokat a nemzetközi közgazdaság-elméleti és ökonometriai buktatókat, melyek nélkül ma már elképzelhetetlen egy konzisztens gravitációs modell összeállítása, valamint egy torzítatlan határhatás-becslés végrehajtása. A leírtakból nyomon követhetö, hogyan változhat - modellspecifikációtól függően - a kulcsváltozó jelentése, interpretálása, valamint az is, hogy a határhatás időbeli alakulása miként szolgálhat egyfajta jelzésként a nemzetközi árupiacok integrációs folyamatát illetően. Az empirikus irodalomból az látszik körvonalazódni, hogy egyelőre kisebbségben vannak azok az írások, amelyek azt állítják, hogy az országhatárok nem akadályozzák a vállalatok közötti kereskedelmet, ceteris paribus. Általában a határváltozó paramétere - a lehető legtöbb tényezőt kontrollálva, valamint a torzítást elöidéző körülményeket kivédve is - pozitív és statisztikailag szignifikáns marad, ami alapján kijelenthetö, hogy a világpiac egy átlagos vállalata túlzottan preferálja a belföldi kereskedelmi partnereket a külföldiekkel szemben.

\section{Hivatkozások}

Anderson, J. E. (1979): A Theoretical Foundation for the Gravity Equation. The American Economic Review, Vol. 69, No. 1:106-116.

Anderson, J. E. - van Wincoop, E. (2003): Gravity with Gravitas: A Solution to the Border Puzzle. The American Economic Review, Vol. 93, No. 1:170-192.

Anderson, M. A. - Smith, S. L. S. (1999a): Canadian Provinces in World Trade: Engagement and Detachment. Canadian Journal of Economics, Vol. 32, No. 1:2238.

Anderson, M. A. - Smith, S. L. S. (1999b): Do National Borders Really Matter? Canada-US Regional Trade Reconsidered. Review of International Economics, Vol. 7, No. 2:219-227.

Andresen, M. A. (2010): The Geography of the Canada-United States Border Effect. Regional Studies, Vol. 44, No. 5:579-594.

Armington, P. S. (1969): A Theory of Demand for Products Distinguished by Place of Production. International Monetary Fund, Staff Papers, Vol. 16, No. 1:159-178.

Baier, S. L. - Bergstrand, J. H. (2009): Bonus Vetus OLS: A Simple Method for Approximating International Trade-cost Effects Using the Gravity Equation. Journal of International Economics, Vol. 77, No. 1:77-85. 
Baldwin, R. - Taglioni, D. (2006): Gravity for Dummies and Dummies for Gravity Equations. No. W12516, National Bureau of Economic Research.

Balta, N. - Delgado, J. (2007): Home Bias and Market Integration in the EU. Cesifo Economic Studies, Vol. 55, No. 1:110-144.

Bergstrand, J. H. (1985): The gravity equation in international trade: Some microeconomic foundations and empirical evidence. The Review of Economics and Statistics, Vol. 67, No. 3:474-481.

Bergstrand, J. H. (1989): The generalized gravity equation, monopolistic competition, and the factor proportions theory in international trade. The Review of Economics and Statistics, Vol. 71, No. 1:143-153.

Chen, N. (2004): Intra-national versus International Trade in the European Union: Why do National Borders Matter? Journal of International Economics, Vol. 63, No. 1:93-118.

Cheng, I. - Wall, H. J. (2005): Controlling for Heterogeneity in Gravity Models of Trade and Integration. Federal Reserve Bank of St. Louis Review, Vol. 87, No. 1:49-63.

Coughlin, C. C. - Novy, D. (2009): Is the International Border Effect Larger than the Domestic Border Effect? Evidence from US Trade. Cesifo Economic Studies, Vol. 59, No. 2:249-276.

Deardorff, A. V. (1998): Determinants of Bilateral Trade. Does Gravity Work in a Neoclassical World? In: The Regionalization of the World Economy. University of Chicago Press:7-32.

Dias, D. A. (2011): The Border Effect Through the Rearview Mirror: Would the Puzzle Have Existed if Today's Tools had been used? Kézirat; University of Illinois at Urbana-Champaign.

Eaton, J. - Kortum, S. (2002): Technology, Geography and Trade. Econometrica, Vol. 70, No. 5:1741-1779.

Engel, C. - Rogers, J. H. (1996): How Wide is the Border? The American Economic Review, Vol. 86, No. 1:1112-1125.

Evans, C. L. (2003): The Economic Significancae of National Border Effects. The American Economic Review, Vol. 93, No. 4:1291-1312.

Feenstra, R. C. (2002): Border Effect and the Gravity Equation: Consistent Methods for Estimation. Scottish Journal of Political Economy, Vol. 49, No. 5:491-506.

Gil-Pareja, S. - Martínez-Serrano, J. A. - Llorca-Vivero, R. - Oliver-Alonso, J. (2004):

The Border Effect in Spain. Documento de trabajo, 2004/28.

Gilpin, R. (2011): Global Political Economy: Understanding the International Economic Order. Princeton University Press.

Head, K. - Mayer, T. (2000): Non-Europe: The Magnitude and Causes of Market Fragmentation in Europe. Weltwirtschaftliches Archiv, Vol. 136, No. 2:285-314. 
Head, K. - Mayer, T. (2002): Illusory Border Effects: Distance Mismeasurement Inflates Estimates of Home Bias in Trade. Working Paper No. 2002-01. Centre d'Etudes Prospectives et d'Informations Internationales (CEPII), Paris.

Helble, M. (2006): Border Effect Estimates for France and Germany Combining International Trade and Intra-national Transport Flows. HEI Working Paper No. $13 / 2006$.

Helliwell, J. F. (1996): Do National Borders Matter for Quebec's Trade? NBER Working Paper, No. 5215.

Helliwell, J. F. (1998): How Much do National Borders Matter? Brookings Institution Press, Washington, DC.

Helliwell, J. F. - Verdier, G. (2001): Measuring Internal Trade Distance: A New Method Applied to Estimate Provincial Border Effect in Canada. The Canadian Journal of Economics, Vol. 43, No. 4:1024-1041.

Hillberry, R. - Hummels, D. (2003): Intranational Home Bias: Some Explanations. The Review of Economics and Statistics, Vol. 85, No. 4:1089-1092.

Horváth Julius - Rátfai Attila - Döme Botond (2008), "The border effect in small open economies.” Economic Systems, Vol. 32, No. 1:33-45.

Krugman, P. (1980): Scale Economies, Product Differentiation and the Pattern of Trade. The American Economic Review, Vol. 70, No. 5:950-959.

Leamer, E. E. (1997): Access to Western Markets, and Eastern Effort Levels. In: Zecchini, S. (Ed.): Lessons from the Economic Transition: Central and Eastern Europe in the 1990s. Kluwer Academic Publishers:503-526.

Llano-Verduras, C. - Minondo, A. - Requena-Silvente, F. (2011): Is the Border Effect an Artefact of Geographical Aggregation? World Economy, Vol. 34, No. 10:11711187.

Márkus Ádám (2017): Disappearing Borders in the Visegrad Countries. Prague Eonomic Papers, Vol. 26, No. ? (megjelenés alatt).

Mátyás László (1997): Proper Econometric Specification of the Gravity Model. The World Economy, Vol. 20, No. 3:363-368.

McCallum, J. (1995): National Borders Matter: Canada-U.S. Regional Trade Patterns. The American Economic Review, Vol. 85, No. 3:615-623.

Milimet, D. L. - Osang, T. (2007): Do State Borders Matter for U.S. Intranational Trade? The Role of History and Internal Migration. Canadian Journal of Economics, Vol. 40, No. 1:93-126.

Nitsch, V. (2000): National Borders and International Trade: Evidence from the European Union. Canadian Journal of Economics, Vol. 33, No. 4:1091-1105.

Obstfeld, M. - Rogoff, K. S. (2001): The Six Major Puzzles in International Macroeconomics: Is There a Common Cause? MIT Press, NBER macroeconomics Annual 2000, Vol. 15:339-412.

Okubo, T. (2003): The Border Effect in The Japanese Market: A Gravity Model Analysis. Journal of the Japanese and International Economies, Vol. 18, No. 1:1-11. 
Okubo, T. (2004): Why Has the Border Effect in the Japanese Market Declined? The Role of Business Network in East Asia. Hi-Stat Discussion Paper Series, Working Paper No. 24.

Olper, A. - Raimondi, V. (2008): Agricultural market integration in the OECD: A gravity-border effect approach. Food Policy, Vol. 33, No. 2:165-175.

Pacchioli, C. (2011): Is the EU Internal Market Suffering from an Integration Deficit? Estimating the 'Home-bias Effect'. CEPS Working Document No. 348.

Pásztor Szabolcs (2014): The Economic Transformation of Borders in Central and Eastern Europe: The Case of Hungary and Its Eastern Borders. Phd diss., University of Debrecen, Debrecen. https://dea.lib.unideb.hu/dea/handle/2437/182110.

Pöyhönen, P. (1963): A Tentative Model for the Volume of Trade Between Countries. Weltwirtschaftliches Archiv, Bd. 90:93-100.

Redding, S. - Venables, A. J. (2000): Economic Geography and International Inequality. Mimeo London School of Economics.

Reich, R. B. (2010): The Work of Nations: Preparing Ourselves for 21st Century Capitalis. Vintage.

Rich, D. C. (1980): Potential Models in Human Geography. Concepts and Techniques in Modern Geography, No. 26.

Rose, A. K. (2000): Does a Currency Union Boost International Trade? California Management Review, Vol. 42, No. 2:52-62.

Rose, A. K. - van Wincoop, E. (2001): National Money as a Barrier to International Trade: The Real Case for Currency Union. The American Economic Review, Vol. 91, No. 2:386-390.

Samuelson, P. A. (1954): The Transfer Problem and Transport Costs, II: Analysis of Effects of Trade Impediments. The Economic Journal, Vol. 64, No. 254:264-289.

Santos Silva, J. M. C. - Tenreyro, S. (2006): The Log of Gravity. The Review of Economics and Statistics, Vol. 88, No. 4:641-658.

Solow, R. M. (1957): Technical change and the aggregate production function. The review of Economics and Statistics, Vol. 39, No. 3:312-320.

Suvankulov, F. (2015): Revisiting National Border Effects in Foreign Trade in Goods of Canadian Provinces. Bank of Canada Working Paper, No. 28.

Tinbergen, J. (1962): Shaping the World Economy - Suggestions for an International Economic Policy. Twentieth Century Fund, New York.

Wei, S-J. (1996): Intra-national versus International trade: How Stubborn are Nations in Global Integration? National Bureau of Economic Research, Working Paper 5531.

Wolf, H. C. (2000): Intranational Home Bias in Trade. The Review of Economics and Statistics, Vol. 82, No. 4:555-563.

Xing, W. - Li, S. (2011): Home Bias, Border Effect and Internal Market Integration in China: Evidence from Inter-provincial Value-added Tax Statistics. Review of Development Economics, Vol. 15, No. 3:491-503. 
Yi, K. M. (2010): Can multistage production explain the home bias in trade? The American Economic Review, Vol. 100, No. 1:364-393.

\section{Melléklet}

\section{1. táblázat: A határhatásra vonatkozó empirikus kutatások modelljeinek legfontosabb jellemzői.}

\begin{tabular}{|c|c|c|c|c|c|c|c|c|}
\hline Szerzö & $\begin{array}{l}\text { Vizsgált } \\
\text { országok }\end{array}$ & $\begin{array}{l}\text { Vizsgált } \\
\text { időszak } \\
\end{array}$ & $\begin{array}{c}\text { Becslés } \\
\text { módszere }\end{array}$ & $\begin{array}{l}\text { Függő változó } \\
\text { (LN) }\end{array}$ & $\begin{array}{c}\text { Magyarázó } \\
\text { változók (LN) }\end{array}$ & $\begin{array}{c}\text { Határhatás } \\
\text { nagysága }\end{array}$ & $\mathrm{N}$ & $\mathrm{R}^{2}$ \\
\hline $\begin{array}{l}\text { McCallum } \\
\text { (1995) }\end{array}$ & Kanada-USA & 1988 & OLS & $\begin{array}{c}\text { Áruszállitás } \\
\text { értéke }_{\mathrm{ij}}\end{array}$ & GDP, távolság & 22 & 683 & 0,811 \\
\hline Wei (1996) & $\begin{array}{c}\text { OECD- } \\
\text { országok }\end{array}$ & 1982-1994 & IV-SUR & Export $_{i j}$ & $\begin{array}{l}\text { GDP, távolság, } \\
\text { szomszédság, } \\
\text { relatív távoliság, } \\
\text { közös nyelv }\end{array}$ & $7,7-2,3$ & 1444 & $\begin{array}{l}0,80- \\
0,88\end{array}$ \\
\hline $\begin{array}{l}\text { Helliwell } \\
(1996)\end{array}$ & $\begin{array}{l}\text { Kanada-USA } \\
\text { (A) } \\
\text { Quebec-USA } \\
\text { (B) }\end{array}$ & $1988-1990$ & OLS & $\begin{array}{c}\text { Áruszállitás } \\
\text { értéke }_{\mathrm{ij}}\end{array}$ & GDP, távolság & $\begin{array}{l}\text { (A): } 24,8-18,5 \\
\text { (B): } 30,9-22,2\end{array}$ & 677 & $\begin{array}{l}0,782- \\
0,803\end{array}$ \\
\hline $\begin{array}{c}\text { Helliwell } \\
(1998)\end{array}$ & Kanada-USA & 1988-1996 & OLS & $\begin{array}{c}\text { Áruszállitás } \\
\text { értéke }_{\mathrm{ij}}\end{array}$ & $\begin{array}{l}\text { GDP, távolság, } \\
\text { relatív távoliság }\end{array}$ & $25,3-11,4$ & n. a. & n. a. \\
\hline $\begin{array}{l}\text { Anderson- } \\
\text { Smith (1999) }\end{array}$ & Kanada-USA & 1988 & OLS & Export $_{\mathrm{ij}}+$ Export $_{\mathrm{ji}}$ & $\begin{array}{l}\text { GDP, GDP/fó, } \\
\text { távolság, szom- } \\
\text { szédság } \\
\end{array}$ & 15,2 & 334 & 0,86 \\
\hline $\begin{array}{c}\text { Anderson- } \\
\text { Smith (1999) }\end{array}$ & Kanada-USA & 1990 & OLS & Export $_{\mathrm{ij}}$ Export $_{\mathrm{ji}}$ & $\begin{array}{l}\text { GDP, GDP/fo", } \\
\text { távolság }\end{array}$ & 14,3 & 55 & 0,951 \\
\hline $\begin{array}{l}\text { Head-Mayer } \\
\quad(2000)\end{array}$ & EU9 & $\begin{array}{l}1984-1986 \\
1979-1990\end{array}$ & $\begin{array}{l}\text { Pooled } \\
\text { OLS }\end{array}$ & Import. Import $_{\text {ii }}$ & $\begin{array}{c}\text { Relatív termelés, } \\
\text { relatív árak, relatív } \\
\text { távolság, közös } \\
\text { nyelv } \\
\end{array}$ & $\begin{array}{c}15,6 \\
20,9-12,7\end{array}$ & $\begin{array}{l}12892 \\
8052- \\
7658 \\
\end{array}$ & $\begin{array}{r}0,417 \\
0,396- \\
0,337 \\
\end{array}$ \\
\hline Nitsch (2000) & EU10 & 1979-1990 & SUR & Export $_{i j}$ & $\begin{array}{l}\text { GDP, távolság, } \\
\text { szomszédság, } \\
\text { közös nyelv, relatív } \\
\text { távoliság }\end{array}$ & 16,4 & 972 & 0,93 \\
\hline Wolf (2000) & $\begin{array}{c}\text { Amerikai } \\
\text { államok }\end{array}$ & 1993 & OLS & $\begin{array}{c}\text { Áruszállitás } \\
\text { értéke }\end{array}$ & $\begin{array}{l}\text { GDP, távolság, } \\
\text { relatív távoliság, } \\
\text { szomszédság }\end{array}$ & 3,3 & 2137 & 0,856 \\
\hline $\begin{array}{l}\text { Helliwell- } \\
\text { Verdier } \\
(2001)\end{array}$ & $\begin{array}{l}\text { Kanada-USA } \\
\qquad(\mathrm{A}) \\
\text { Kanadai pro- } \\
\text { vinciák (B) }\end{array}$ & 1991-1996 & OLS & $\begin{array}{l}\text { Áruszállitás } \\
\text { értéke }_{i j}\end{array}$ & $\begin{array}{l}\text { GDP, távolság, } \\
\text { relatív távoliság }\end{array}$ & $\begin{array}{l}\text { (A): } 14,7-10,2 \\
\text { (B): } 29,2-1\end{array}$ & 687 & $\begin{array}{r}0,774- \\
0,792\end{array}$ \\
\hline
\end{tabular}


MÁRKUS ÁDÁM

\begin{tabular}{|c|c|c|c|c|c|c|c|c|}
\hline Szerzö & $\begin{array}{l}\text { Vizsgált } \\
\text { országok }\end{array}$ & $\begin{array}{l}\text { Vizsgált } \\
\text { időszak }\end{array}$ & $\begin{array}{l}\text { Becslés } \\
\text { módszere }\end{array}$ & $\begin{array}{l}\text { Függő változó } \\
\text { (LN) }\end{array}$ & $\begin{array}{c}\text { Magyarázó } \\
\text { változók (LN) }\end{array}$ & $\begin{array}{c}\text { Határhatás } \\
\text { nagysága }\end{array}$ & $\mathrm{N}$ & $\mathrm{R}^{2}$ \\
\hline $\begin{array}{l}\text { Feenstra } \\
(2002)\end{array}$ & $\begin{array}{c}\text { Kanada-USA } \\
\text { és USA-Ka- } \\
\text { nada átlag }\end{array}$ & 1993 & OLS & $\begin{array}{c}\text { Áruszállitás } \\
\text { értéke } \mathrm{e}_{\mathrm{ij}} / \mathrm{GDP}_{\mathrm{i}}^{*} \mathrm{G}^{-} \\
\mathrm{DD}_{\mathrm{j}}\end{array}$ & $\begin{array}{l}\text { Provincia és állam } \\
\text { dummyk, távolság }\end{array}$ & 4,7 & 1511 & 0,66 \\
\hline $\begin{array}{l}\text { Head-Mayer } \\
\text { (2002) }\end{array}$ & $\begin{array}{l}\text { EU12 (A) } \\
\text { Amerikai } \\
\text { államok (B) }\end{array}$ & $\begin{array}{c}1993-1995 \\
1997\end{array}$ & $\begin{array}{l}\text { (A): Poo- } \\
\text { led OLS } \\
\text { (B): OLS }\end{array}$ & Import $_{\text {ij }}$ Import $_{\text {ii }}$ & $\begin{array}{l}\text { GDP, távolság, } \\
\text { szomszédság, } \\
\text { közös nyelv }\end{array}$ & $\begin{array}{l}\text { (A): } 4,2 \\
\text { (B): } 6,4\end{array}$ & $\begin{array}{l}7213 \\
5841\end{array}$ & $\begin{array}{r}0,276 \\
0,38\end{array}$ \\
\hline $\begin{array}{c}\text { Hillberry- } \\
\text { Hummels } \\
(2003)\end{array}$ & $\begin{array}{l}\text { Amerikai } \\
\text { államok }\end{array}$ & 1997 & OLS & $\begin{array}{l}\text { Áruszállitás } \\
\text { értéke }_{\mathrm{ij}}\end{array}$ & $\begin{array}{l}\text { Ország-dummy, } \\
\text { távolság }\end{array}$ & 1,6 & 2304 & 0,911 \\
\hline Okubo (2003) & Japán & $\begin{array}{l}1960 \\
1965 \\
1970 \\
1975 \\
1980 \\
1985 \\
1990\end{array}$ & OLS & Export $_{i j}$ & GDP, távolság & $\begin{array}{l}8,57 \\
8,85 \\
10,38 \\
6,42 \\
3,6 \\
4,58 \\
3,41\end{array}$ & 200 & $\begin{array}{r}0,67- \\
0,81\end{array}$ \\
\hline $\begin{array}{c}\text { Anderson- } \\
\text { van Wincoop } \\
(2004)\end{array}$ & Kanada-USA & 1993 & NLLS & $\begin{array}{c}\text { Áruszállítás } \\
\text { értéke }_{\mathrm{ij}}\end{array}$ & $\begin{array}{l}\text { GDP, távolság, } \\
\text { multilaterális } \\
\text { kereskedelemi } \\
\text { akadályok }\end{array}$ & 10,5 & 679 & n. a. \\
\hline Chen (2004) & $\begin{array}{l}\text { EU7 (FRA, } \\
\text { GER, ITA, } \\
\text { UK, ESP, FIN, } \\
\text { POR) }\end{array}$ & 1996 & $\begin{array}{l}\text { Tobit } \\
\text { becslés }\end{array}$ & $1+$ Export $_{\mathrm{j} / \mathrm{k}}$ & $\begin{array}{l}\text { GDP, távolság, } \\
\text { szomszédság, } \\
\text { tömeg/érték }\end{array}$ & $\begin{array}{l}\text { GER: 2,6 } \\
\text { UK: 3,2 } \\
\text { FRA: 7,1 } \\
\text { ITA: 7,5 } \\
\text { POR: 7,8 } \\
\text { ESP: 9,0 } \\
\text { FIN: } 38,5\end{array}$ & 3822 & 0,421 \\
\hline Okubo (2004) & Japán & 1980-1995 & GLS & Gépipari export & GDP, távolság & $11-0,2$ & $\begin{array}{r}2366- \\
1880\end{array}$ & n. a. \\
\hline
\end{tabular}


A HATÁRHATÁS IRODALOM ÁTTEKINTÉSE

\begin{tabular}{|c|c|c|c|c|c|c|c|c|}
\hline Szerző & $\begin{array}{l}\text { Vizsgált } \\
\text { országok }\end{array}$ & $\begin{array}{l}\text { Vizsgált } \\
\text { időszak }\end{array}$ & $\begin{array}{c}\text { Becslés } \\
\text { módszere }\end{array}$ & $\begin{array}{l}\text { Függő változó } \\
\text { (LN) }\end{array}$ & $\begin{array}{c}\text { Magyarázó } \\
\text { változók (LN) }\end{array}$ & $\begin{array}{c}\text { Határhatás } \\
\text { nagysága }\end{array}$ & $\mathrm{N}$ & $\mathrm{R}^{2}$ \\
\hline $\begin{array}{l}\text { Gil-Pareja et } \\
\text { al. (2005) }\end{array}$ & Spanyolország & 1995-1998 & $\begin{array}{l}\text { Véletlen } \\
\text { hatású } \\
\text { panel }\end{array}$ & Export $_{i j}$ & $\begin{array}{l}\text { GDP, távolság, EU/ } \\
\text { EFTA, szomszéd- } \\
\text { ság, sziget }\end{array}$ & 2,61 & 3808 & 0,74 \\
\hline Helble (2006) & $\begin{array}{l}\text { Németország } \\
\qquad \text { (A) } \\
\text { Franciaország } \\
\text { (B) }\end{array}$ & 2002 & OLS & $\begin{array}{l}\text { Régiók kereske- } \\
\text { delme szállitási } \\
\text { adatokból }\end{array}$ & $\begin{array}{l}\text { Ország-dum- } \\
\text { my, távolság, } \\
\text { szomszédság, } \\
\text { közös valuta, üzleti } \\
\text { infrastruktúra }\end{array}$ & $\begin{array}{l}\text { (A): } 3,1 \\
\text { (B): } 7\end{array}$ & $\begin{array}{l}870 \\
1190\end{array}$ & $\begin{array}{l}0,625 \\
0,852\end{array}$ \\
\hline $\begin{array}{c}\text { Millimet- } \\
\text { Osang (2007) }\end{array}$ & $\begin{array}{l}\text { Amerikai } \\
\text { államok }\end{array}$ & 1993, 1997 & OLS & $\begin{array}{l}\text { Áruszállitás } \\
\text { értéke }{ }_{i j}\end{array}$ & $\begin{array}{c}\text { GDP, távolság, } \\
\text { szomszédság, } \\
\text { fogyasztói árindex, } \\
\text { bér, GSP-deflátor }\end{array}$ & $\begin{array}{l}4,6 \\
5,4\end{array}$ & $\begin{array}{l}2137 \\
2091\end{array}$ & $\begin{array}{l}0,88 \\
0,87\end{array}$ \\
\hline $\begin{array}{l}\text { Olper-Rai- } \\
\text { mondi (2008) }\end{array}$ & $\begin{array}{l}\text { OECD-or- } \\
\text { szágok }\end{array}$ & 1994-2003 & $\begin{array}{c}\text { PPML (fix } \\
\text { hatás) }\end{array}$ & Agrárexport & $\begin{array}{l}\text { Ország-dummy, } \\
\text { távolság, szom- } \\
\text { szédság, közös } \\
\text { nyelv, év-dummy }\end{array}$ & 11,4 & 4840 & 0,982 \\
\hline $\begin{array}{l}\text { Coughlin- } \\
\text { Novy (2009) }\end{array}$ & $\begin{array}{l}\text { Amerikai } \\
\text { államok (A) } \\
\text { USA (B) }\end{array}$ & $\begin{array}{c}1993,1997, \\
2002\end{array}$ & $\begin{array}{l}\text { Véletlen } \\
\text { hatású } \\
\text { panel }\end{array}$ & $\begin{array}{l}\text { Áruszállitás } \\
\text { értéke }_{\mathrm{ij}}\end{array}$ & $\begin{array}{l}\text { GDP, távolság, } \\
\text { szomszédság }\end{array}$ & $\begin{array}{l}\text { (A): } 4,4 \\
\text { (B): } 3,6\end{array}$ & 12417 & 0,79 \\
\hline $\begin{array}{l}\text { Andresen } \\
(2010)\end{array}$ & $\begin{array}{c}\text { Kanadai } \\
\text { provinciák- } \\
\text { USA }\end{array}$ & 1989-2001 & $\begin{array}{l}\text { Rögzített } \\
\text { hatású } \\
\text { panel }\end{array}$ & Export $_{i j}$ & $\begin{array}{l}\text { GDP, GDP/fö, } \\
\text { tőke/munka, föld/ } \\
\text { munka, provin- } \\
\text { ciapár-dummy, } \\
\text { év-dummy }\end{array}$ & $9,9-0,03$ & 14170 & 0,89 \\
\hline Yi (2010) & Kanada-USA & 1990 & OLS & $\begin{array}{c}\text { Modell alapján } \\
\text { kalibrált kereske- } \\
\text { delmi áramlás/ } \\
\text { GDP }\end{array}$ & Távolság & 9,2 & 6 & n. a. \\
\hline Dias (2011) & Kanada-USA & 1988 & PPML & $\begin{array}{l}\text { Áruszállitás } \\
\text { értéke }_{\mathrm{ij}}\end{array}$ & GDP, távolság & 12,8 & 679 & n. a. \\
\hline $\begin{array}{l}\text { Llano Ver- } \\
\text { duras et al. } \\
\text { (2011) }\end{array}$ & Spanyolország & 2000,2005 & PPML & Iparági export $_{i j}$ & $\begin{array}{l}\text { GDP, távolság, } \\
\text { iparág-dummy, } \\
\text { szomszédság }\end{array}$ & 6,9 & 78208 & n. a. \\
\hline $\begin{array}{l}\text { Pacchioli } \\
\text { (2011) }\end{array}$ & $\begin{array}{l}\text { Amerikai } \\
\text { államok (A) } \\
\text { EU14 (EU15 } \\
\text { Görögország } \\
\text { nélkül) (B) }\end{array}$ & 1996-2002 & $\begin{array}{l}\text { Rögzített } \\
\text { hatású } \\
\text { panel }\end{array}$ & $\begin{array}{c}\text { Áruszállitás }_{\text {értéke }} \\
\text { Export }_{i j}\end{array}$ & $\begin{array}{l}\text { GDP vagy GSP, } \\
\text { távolság, szom- } \\
\text { szédság, közös } \\
\text { nyelv, ország- vagy } \\
\text { állam-dummy, } \\
\text { év-dummy }\end{array}$ & $\begin{array}{l}\text { (A): } 2,6 \\
\text { (B): } 7,5\end{array}$ & 4054 & 0,893 \\
\hline $\begin{array}{l}\text { Xing-Li } \\
\text { (2011) }\end{array}$ & $\begin{array}{l}\text { Kínai provin- } \\
\text { ciák }\end{array}$ & $\begin{array}{l}2004 \\
2005\end{array}$ & OLS & $\begin{array}{l}\text { Áruszállitás } \\
\text { értéke }_{i j}\end{array}$ & $\begin{array}{l}\text { GDP, távolság, } \\
\text { relatív távoliság }\end{array}$ & $\begin{array}{l}3 \\
3,6\end{array}$ & 900 & $\begin{array}{l}0,805 \\
0,82\end{array}$ \\
\hline
\end{tabular}


MÁRKUS ÁDÁM

\begin{tabular}{|c|c|c|c|c|c|c|c|c|}
\hline Szerzö & $\begin{array}{l}\text { Vizsgált } \\
\text { országok }\end{array}$ & $\begin{array}{l}\text { Vizsgált } \\
\text { időszak }\end{array}$ & $\begin{array}{c}\text { Becslés } \\
\text { módszere }\end{array}$ & $\begin{array}{l}\text { Függő változó } \\
\text { (LN) }\end{array}$ & $\begin{array}{c}\text { Magyarázó } \\
\text { változók (LN) }\end{array}$ & $\begin{array}{c}\text { Határhatás } \\
\text { nagysága }\end{array}$ & $\mathrm{N}$ & $\mathrm{R}^{2}$ \\
\hline $\begin{array}{l}\text { Suvankulov } \\
\text { (2015) }\end{array}$ & $\begin{array}{l}\text { Kanada-USA } \\
\text { (A) } \\
\text { Kanada-EU } \\
\text { (B) } \\
\text { Kanada-G20 } \\
\text { (C) } \\
\end{array}$ & 2001-2010 & $\begin{array}{l}\text { PPML } \\
\text { - IV }\end{array}$ & $\begin{array}{l}\text { Áruszállítás } \\
\text { értéke }_{\mathrm{ij}}\end{array}$ & $\begin{array}{l}\text { GDP, távolság, ár- } \\
\text { folyam, FDI, közös } \\
\text { nyelv, szomszéd- } \\
\text { ság, gyarmati múlt, } \\
\text { vám, WTO tagság, } \\
\text { nem vámjellegü } \\
\text { eszközök, relatív } \\
\text { távoliság }\end{array}$ & $\begin{array}{l}\text { (A): } 4,8 \\
\text { (B): } 15,2 \\
\text { (C): } 5,5\end{array}$ & 19300 & n. a. \\
\hline $\begin{array}{l}\text { Márkus } \\
\text { (2017) }\end{array}$ & $\begin{array}{l}\text { Visegrádi } \\
\text { négyek }\end{array}$ & 1995-2011 & $\begin{array}{l}\text { PPML } \\
\text { (fix hatás) }\end{array}$ & Export $_{i j}$ & $\begin{array}{l}\text { Évenkénti or- } \\
\text { szág-dummy, } \\
\text { országpár-dummy, } \\
\text { közös valuta }\end{array}$ & $\begin{array}{l}\text { HUN:1-0,06 } \\
\text { CZE:1-0,2 } \\
\text { SVK:1-0,08 } \\
\text { POL: 1-0,2 }\end{array}$ & 3264 & 1,000 \\
\hline
\end{tabular}

Megjegyzés: $\mathrm{N}$ a megfigyelések számát, $\mathrm{R}^{2}$ a determinációs együtthatót jelenti. A magyarázók változók között - bár a táblázatban nem szerepel - természetesen minden modellben jelen van a határ-dummy. N. a. akkor szerepel egy cellában, ha az adott tényezőről nem áll rendelkezésre az információ a cikk alapján. Pooled OLS: egyesített keresztmetszeti mintán végrehajtott becslés. IV: instrumentumváltozó használata. SUR: látszólag nem összefüggő regresszió. NLLS: nem-lineáris legkisebb négyzetek módszere. GLS: általánosított legkisebb négyzetek módszere. Határhatás nagysága = Exp(határ-dummy paramétere). Ahol a határhatás nagysága $=1$, ott az országhatár nem befolyásolja szignifikánsan a kereskedelmet, ceteris paribus $\left(\mathrm{e}^{0}=1\right)$. Számos kutatás esetén többféle regresszió is lefuttatásra kerül érzékenységi vizsgálat gyanánt, ám minden esetben csak a legjellemzőbb, az irodalmat előremozdító egyenlet tulajdonságai szerepelnek a táblázatban. 